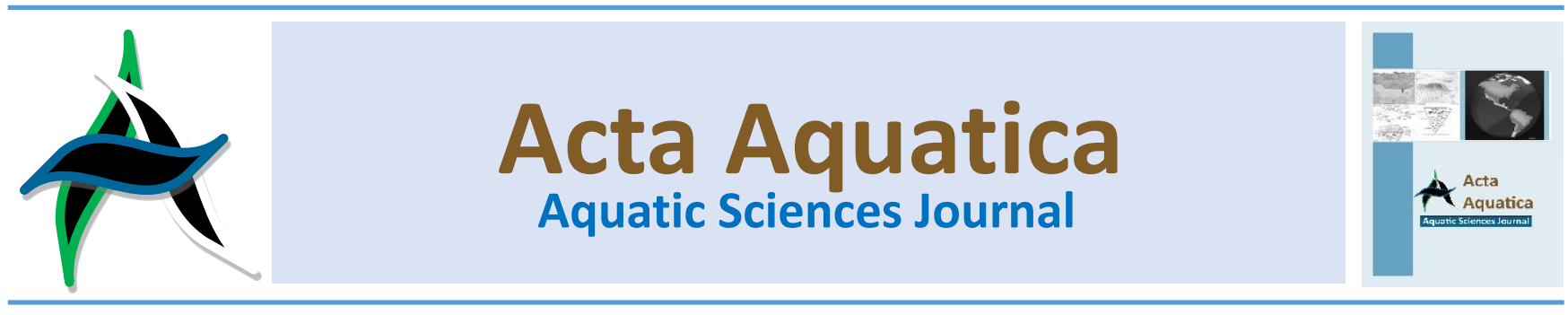

\title{
Profit comparative of fisheries in East Aceh Regency, Indonesia
}

\author{
Mawardati $^{a, *}$, and Jullimursyida ${ }^{b}$ \\ ${ }^{a}$ Department of Agribusiness, Faculty of Agriculture, Universitas Malikussaleh \\ ${ }^{b}$ Department of Management, Faculty of Economics and Business, Universitas Malikussaleh
}

\begin{abstract}
This research was conducted from March to May 2018 in East Aceh District, Aceh Province, Indonesia. This study aims to analyze the differences between traditional milkfish and shrimp culture in East Aceh District, Aceh Province. The analytical method used is acquisition analysis and Independent sample $t$-test analysis. The results showed a significant difference between milkfish and shrimp culture in East Aceh District, Aceh Province. Based on the results of the analysis, the average profit from shrimp culture is higher than milkfish culture. This demand exceeds market demand for exports. Thus the price of shrimp is still far higher than milkfish.
\end{abstract}

Keywords: comparative; profit; shrimp; milkfish

\section{Introduction}

The agricultural sector is one sector that has a significant contribution to the development of the Indonesian economy. This can be seen among others through the provision of employment, the fulfilment of domestic needs and foreign exchange earnings through exports. In general, the agricultural sector is developing through several sub-sectors, namely: 1) the food crops sub-sector, 2) the plantation sub-sector, 3) the forestry sub-sector, 4) the livestock subsector, and 5) the fisheries sub-sector.

As with other sub-sectors, the fisheries sub-sector also has considerable opportunities to continue to be developed because Indonesia has a fairly large area of water. Therefore, many Indonesians depend on the fisheries subsector for both marine and inland fisheries. Many people living in coastal areas work as fishermen and some others as fish farmers. According to Dahuri et al., (1996), fishery activities in coastal areas are aquaculture business in fish ponds for shrimp and milkfish.

East Aceh Regency Aceh Province is one of the areas with high potential for fisheries business development. The development of the fisheries business in this district was initially focused on the milkfish culture due to overtime the farmers began to switch to the shrimp culture business. This is obviously because the price of shrimp is much higher than the price of milkfish, coupled with high market demand, both domestic and export markets for shrimp commodity. The presence of vanamae

*Corresponding author: Department of Agribussines, Faculty of Agriculture, Universitas Malikussaleh. Jl. Universitas. Kec. Muara Batu, Kabupaten Aceh Utara, Provinsi Aceh, 24355, Indonesia.

Tel: +62-645-41373 Fax: +62-645-59089

e-mail: mawardati@unimal.ac.id

doi: http://doi.org/10.29103/aa.v7i2.2510
Although the price of shrimp is higher than the price of milkfish, shrimp price has fluctuated, and production costs are also much higher than milkfish. Besides, shrimp culture, especially vanamae shrimp, also has a high risk of being susceptible to disease pests and even experiencing crop failure, and the seeds or shrimp fry are still commercially developed because they originate from imported broodstock (Haliman et al., 2005). While the milkfish culture business besides having a lower risk, milkfish prices also tend to be more stable than shrimp prices. Another advantage of milkfish is that they are able to adapt to changes in the environment (temperature, $\mathrm{pH}, \mathrm{dry}$ ) and are resistant to disease attacks (Ghufron, 2000). However, most farmers in East Aceh Regency still choose to switch to shrimp culture rather than sticking to milkfish culture.

Regarding the data above, this study aims to compare the profit gap between shrimp culture and milkfish culture to provide opportunities for farmers in determining the type of business related to business profits and for the government to be the basis in making policies related to the development of fisheries business because these two types of commodities are needed both for domestic needs and export needs.

\section{Materials and methods}

This research was conducted in East Aceh Regency using a survey method. The population in this study were milkfish farmers and shrimp farmers. The sample location was determined randomly from all districts that had milkfish farmers and shrimp farmers so that 2 (two) districts were selected, namely Julok and Bagok Districts. Furthermore, by using the snowball technique (snowball sampling) as a sampling technique with a total sample of 60 families (KK) of fish farmers consisting of 30 families of milkfish farmers and 30 families of shrimp farmers. 
Analysis of the data in this study uses quantitative descriptive methods, namely, the analysis of profit and the different test of profit. To calculate the profit the formula is used:

$$
\pi_{\mathrm{i}}=\mathrm{TRi}-\mathrm{Tci}
$$

Where:

$$
\begin{array}{ll}
\pi_{\mathrm{i}} & =\text { Profit of group } \mathrm{i} \\
\mathrm{TR} & =\text { Total revenue of group } \mathrm{i} \\
\mathrm{TC} & =\text { Total Cost of group } \mathrm{i}
\end{array}
$$

Meanwhile, to analyze the differences in the benefits of milkfish and shrimp culture was used the Independent Sample $t$-test. This analysis is a type of statistical test that aims to compare the average of two groups that are not paired with or related to each other. Non-pairing means that research is conducted for two different sample subjects. Before testing it must be known whether the variance is the same (equal variance) or the variance is different (unequal variance). Homogeneity of variants was tested according to the formula:

$$
F=\frac{s_{1}{ }^{2}}{s_{2}{ }^{2}}
$$

Where:

$\mathrm{F} \quad=\mathrm{F}$ value calculated

$\mathrm{S}_{1}{ }^{2}=$ Highest variant value

$\mathrm{S}_{2}{ }^{2}=$ Lowest variant value

If the analysis shows Levene's Test for Equality of Variance F sig. $>0.05$ then the variant data on milkfish profit and shrimp profits is homogeneous. Conversely, if Levene's Test for not Equality of Variance $F$ value sig. $<0.05$ then the data variance of milkfish business profit and shrimp profit is not homogeneous. $t$-test for homogeneous variants using the Polled Variance formula as follows:

$$
\mathrm{t}=\frac{\overline{\mathrm{X}}_{1}-\overline{\mathrm{X}}_{2}}{\sqrt{\frac{\left(\mathrm{n}_{1}-1\right) \mathrm{s}_{1}^{2}+\left(\mathrm{n}_{2}-1\right) \mathrm{s}_{2}^{2}}{\mathrm{n}_{1}+\mathrm{n}_{2}-2}\left(\frac{1}{n_{1}}+\frac{1}{n_{2}}\right)}}
$$

$t$-test for non-homogeneous variants using the Separated Variance formula as follows:

$$
t=\frac{\bar{x}_{1}-\bar{x}_{2}}{\sqrt{\frac{S_{1}^{2}}{n_{1}}+\frac{S_{2}^{2}}{n_{2}}}}
$$

Where:

$\overline{X_{1}}=$ Average milkfish business profit (IDR /production process)

$\overline{X_{2}}=$ Average shrimp business profit (IDR / production process)

$\mathrm{S}_{1}{ }_{1}=$ Milkfish profit variance

$\mathrm{S}_{2}{ }_{2}=$ Shrimp profit variance

$\mathrm{n}_{1}=$ Number of milkfish farmers sample (People)

$\mathrm{n}_{2}=$ Number of shrimp farmers sample (People)

Criteria of decision making in the independent sample $t$ test used in this study are as follows.

1. If the Sig. (2-tailed) $>0.05$ means that there is no difference in the average profitability of milkfish and shrimp business.
2. If the Sig. (2-tailed) $<0.05$ means that there is no difference in the average profitability of milkfish and shrimp business (Sujarweni, 2014).

\section{Result and discussion}

3.1. Production costs in the milkfish and shrimp culture business in East Aceh District

Production costs are a component that is needed in the production process. Low and high production of milkfish and shrimp produced by farmers in the study location is most influenced by the availability of capital owned by these farmers. Likewise, in selecting a type of business that will be run by farmers in the study location. Farmers who have greater costs or capital tend to choose shrimp culture. Conversely, those who have limited costs generally choose to become milkfish farmers. The results showed that the average production costs used by milkfish farmers and shrimp farmers at the research location are shown in Table 1.

Table 1

Average production costs of milkfish culture and shrimp culture businesses in East Aceh Regency.

\begin{tabular}{lcc}
\hline \multicolumn{1}{c}{ Size } & $\begin{array}{c}\text { Milkfish culture business } \\
\text { (IDR) }\end{array}$ & $\begin{array}{c}\text { Shrimp culture } \\
\text { business (IDR) }\end{array}$ \\
\hline Average value & $29,416.083 .33$ & $51,267,333.60$ \\
Maximum value & $39,720,000.00$ & $64,084,167.00$ \\
Minimum value & $18,695,500.00$ & $50,234,776.00$ \\
\hline
\end{tabular}

There are differences in the average use of production costs in milkfish culture and shrimp culture in East Aceh District, Aceh Province. The high cost of production in shrimp culture is due to the high cost of equipment such as the use of windmills, while the culture of milkfish does not use waterwheel. In addition, maintenance of shrimp culture is more considerable in labor costs because shrimp are more vulnerable to pest and disease attacks than milkfish.

\subsection{Profit and analysis of profit differences in the milkfish and shrimp culture business in East Aceh District}

Profit is the difference between total revenue and the total cost incurred in the business. Because the total revenue is the multiplication of production with the selling price, the amount of production and the price also influences the size of the profits. The results showed that the average profit, maximum profit and minimum profit in milkfish culture and shrimp culture are shown in Table 2 below:

Table 2

Average profit of milkfish culture and shrimp culture in East Aceh District.

\begin{tabular}{lcc}
\hline \multicolumn{1}{c}{ Size } & $\begin{array}{c}\text { average profits of milkfish } \\
\text { culture/production } \\
\text { process }\end{array}$ & $\begin{array}{c}\text { average profits of } \\
\text { shrimp culture/ } \\
\text { production process }\end{array}$ \\
\hline Average value & $12,906,838.70$ & $44,053,387.50$ \\
Maximum value & $14,670,000.00$ & $56,879,650.00$ \\
Minimum value & $12,000,000.00$ & $32,000,000.00$ \\
\hline
\end{tabular}

According to the result analysis in Table 2 shows that the average profit of shrimp culture is higher than milkfish culture. This can be explained that although the average production cost in shrimp culture is higher, it is also followed by high shrimp price so that the profits obtained are also higher when compared to milkfish culture. However, to prove whether or not the difference is statistically significant is analyzed by a different profit test. 
The different test results using independent sample test shows that the Sig. Levene's Test for Equality of Variance is 0.02 $<0.05$ which means that the data variance between the average benefits of milkfish culture and shrimp culture is not the same or not homogeneous (Sujarweni, 2014). Therefore, henceforth must be guided by the values contained in the Equal variances not assumed table in the Independent Samples Test output.

The output results in the variances not assumed equal column show the significant value ( 2 -tailed) of $0.043<0.05$. Thus it can be concluded that there is a significant difference between the average profit in the milkfish culture business and the shrimp culture business in East Aceh District, Aceh Province. In line with Husein et al. (2016) also found that there were significant differences in costs and benefits between monoculture and polyculture of milkfish and shrimp fisheries in Pangkep Regency.

\section{Conclusion}

There is a profit difference in the fishery business between milkfish and shrimp culture in East Aceh Regency, Aceh Province. This gap caused by the price of shrimp, although fluctuating, but tends to be higher than the price of milkfish because shrimp produced by farmers is mainly used for export needs. For developing the milkfish and shrimps culture in East Aceh Regency, this study can give suggestions which are efforts to increase milkfish income can be done by creating added value through the development of milkfish-based agro-industry, given the high consumer demand for processed milkfish. There is a tendency for farmers to grow shrimp compared to milkfish due to the selling price factor and higher profit share. For this reason, the government needs to develop the shrimp export share and develop a shrimp marketing partnership between farmers and large traders.

\section{Bibliography}

Anonymous., 2015. Aceh Marine and Fisheries Department Annual Report 2015. Aceh Marine and Fisheries Office.

Dahuri, R., Rais, J., Ginting, S.P., Sitepu, M.J., 1996. Integrated Coastal and Ocean Resource Management. Jakarta. PT. Pramadiya Paramita.

Haliman, R.W., Adijaya, S.D., 2005. Vannamei Shrimp, Culture and Prospect of Disease-Resistant White Shrimp Market. Jakarta. Penebar Swadaya.

Husain, T.K., Mulyo, J.H., Jamhari, 2016. Analisis Perbandingan Keuntungan dan Risiko Usaha Perikanan Rakyat Sistem Monokultur dan Polikultur di Kabupaten Pangkep. Agro Economic Journal, 27(2): 16-29.

Sujarweni, V.W., 2014. Research Methods: Complete, Practical, and Easy to Understand. Yogyakarta. New Library Press. 